\title{
Some features of blood pressure variability in patients with arterial hypertension in various modes of antihypertensive therapy
}

\author{
0. V. Kanishcheva ${ }^{\mathbb{D} * 1, A-D}$, I. V. Shop ${ }^{1, A, C, D}$, T. M. Tykhonova ${ }^{1, C, F}$, N. I. Imanova ${ }^{(\mathbb{D} 2, B, E}$, \\ M. V. Pochynska $\mathbb{D}^{1, \mathrm{~B}}$
}

${ }^{1}$ V. N. Karazin Kharkiv National University, Ukraine, ${ }^{2}$ Kharkiv Medical Academy of Postgraduate Education, Ukraine

A - research concept and design; B - collection and/or assembly of data; C - data analysis and interpretation; D - writing the article; $\mathrm{E}$ - critical revision of the article; $\mathrm{F}$ - final approval of the article

Key words:

arterial

hypertension,

chronotherapy,

blood pressure

variability,

ambulatory

blood pressure

monitoring.

Zaporozhye

medical journal

2020; $22(3), 290-295$

*E-mail:

elena.petrenko@

karazin.ua
Aim. The study objective was to compare different timing modes of hypertension medications dosing in patients with arterial hypertension in relation to blood pressure level and variability.

Materials and methods. The study included 103 subjects with previously diagnosed AH in whom 24h ambulatory blood pressure monitoring records of adequate quality were obtained. Participants were stratified to three groups based on timing of hypertension medications dosing - morning dosing (group 1), bedtime dosing (group 2), and as needed (group 3). The last one included patients with low compliance of prescribed medications and irregular antihypertensive drugs intake. The systolic and diastolic blood pressure variability indices - standard deviation (VAR1) and root-mean-square value of the difference between consecutive blood pressure measurements (VAR2) were calculated. The Kruskal-Wallis ANOVA or $X^{2}$-test, as appropriate, was used to compare the groups. A two-sided $\mathrm{P}$ value $<0.05$ was considered statistically significant. Analysis of data included corrections for multiple comparisons.

Results. Statistically significant differences were found in mean 24-h diastolic blood pressure values between groups 1 and 3, 2 and $3(P=0.02)$, awake mean diastolic blood pressure values between groups 1 and $3(P=0.03)$ and for VAR1 night-time systolic blood pressure between groups 1 and 3,2 and $3(P<0.05)$. There were no significant differences between any of the studied parameters between the groups with the morning and evening dosing of antihypertensive drugs.

Conclusions. Treatment mode does not significantly affect the short-term variability of blood pressure, determined by the standard deviation from the mean blood pressure and the root-mean-square value of the difference between consecutive blood pressure measurements for a given time period.
Кнючові слова: артеріальна гіпертензія, хронотерапія, варіабельність артеріального тиску, Аобове моніторування артеріального тиску.

Запорізький медичний журнал 2020. T. 22, № 3(120) C. $290-295$

\section{Особливості варіабельності артеріального тиску у хворих на артеріальну гіпертензію на тлі різних режимів гіпотензивної терапії}

\section{О. В. Каніщева, І. В. Шоп, Т. М. Тихонова, Н. І. Іманова, М. В. Починська}

Мета роботи - визначити ступінь впливу різних режимів гіпотензивної терапії на досягнення цільових значень і показники варіабельності артеріального тиску в пацієнтів з артеріальною гіпертензією.

Матеріали та методи. У дослідження залучили 103 пацієнти із раніше діагностованою артеріальною гіпертензією. Усім хворим виконали добове моніторування артеріального тиску. Учасників поділили на групи залежно від часу приймання медикаментів: група 1 - пацієнти, які приймали гіпотензивні препарати 1 раз на день у першій половині дня; група 2 - хворі, які приймали хоча б один гіпотензивний препарат увечері, після 18.00; група 3 - пацієнти, які приймали гіпотензивні препарати епізодично, за потреби. Групи дослідження зіставні за статтю, віком. Варіабельність артеріального тиску оцінювали за допомогою індексів: ВАР1 - стандартне відхилення від середнього значення артеріального тиску для конкретного періоду; ВАР2 - середньоквадратичне значення різниці між послідовними вимірюваннями артеріального тиску. Групи порівнювали методом дисперсійного аналізу Краскела-Волліса, для якісних ознак розраховували критерій $X^{2}$ Пірсона з поправкою Єйтса.

Результати. Статистично значущі відмінності виявили для середніх значень діастолічного артеріального тиску за 24 год між групами 1 i 3,2 і 3 ( $p=0,02)$ і в період денної активності між групами 1 і 3 ( $p=0,03)$, а також для ВАР1 систолічного артеріального тиску в нічний період між групами 1 i 3,2 i 3 ( $p<0,05)$. Між групами з ранковим і вечірнім прийманням гіпотензивних препаратів не встановили вірогідні відмінності за жодним із параметрів, що визначали.

Висновки. Режим терапії не має вірогідного впливу на короткострокову варіабельність артеріального тиску, яку визначали за допомогою стандартного відхилення від середнього значення артеріального тиску й середньоквадратичного значення різниці між послідовними вимірюваннями артеріального тиску для конкретного часового проміжку.

\section{Особенности вариабельности артериального давления у больных артериальной гипертензией на фоне различных режимов гипотензивной терапии}

\section{Е. В. Канищева, И. В. Шоп, Т. М. Тихонова, Н. И. Иманова, М. В. Починская}

Цель работы - определить степень влияния различных режимов гипотензивной терапии на достижение целевых значений и показатели вариабельности артериального давления у пациентов с артериальной гипертензией. 
Материалы и методы. В исследование включили 103 пациентов с ранее диагностированной артериальной гипертензией. Всем пациентам проведено суточное мониторирование артериального давления. Участников поделили на 3 группы в зависимости от времени приема медикаментов: группа 1 - пациенты, принимающие гипотензивные препараты 1 раз в день в первой половине дня; группа 2 - больные, принимающие хотя бы один гипотензивный препарат вечером, после 18.00; группа 3 - пациенты, принимающие гипотензивные препараты эпизодически, по требованию. Изучаемые группы сопоставимы по полу и возрасту пациентов. Вариабельность артериального давления оценивали с помощью индексов: ВАР1 - стандартное отклонение от среднего значения артериального давления для данного временного периода; ВАР2 среднеквадратичное значение разности между последовательными измерениями артериального давления. Группы сравнивали методом дисперсионного анализа Краскела-Уоллиса, для качественных признаков рассчитывали критерий $\mathrm{X}^{2}$ Пирсона с поправкой Йейтса.

Результаты. Статистически значимые различия установлены для средних значений диастолического артериального давления за 24 ч между группами 1 и 3, 2 и 3 ( $p=0,02)$ и в период дневной между группами 1 и 3 ( $p=0,03)$, а также и для ВАР1 систолического артериального давления в ночной период между группами 1 и 3, 2 и 3 (р < 0,05). Между группами с утренним и вечерним приемом гипотензивных препаратов значимые различия ни по одному из изучаемых параметров не обнаружены.

Выводы. Режим терапии не оказывает существенного влияния на краткосрочную вариабельность артериального давления, определяемую при помощи стандартного отклонения от среднего значения артериального давления и среднеквадратичного значения разности между последовательными измерениями артериального давления для данного временного периода.

Arterial hypertension $(\mathrm{AH})$ is one of the leading causes of cardiovascular disease (CVD) mortality in the world [1,2]. Despite the advances of modern science and a wide choice of antihypertensive drugs, some questions of effective management of patients with hypertension remain of current interest today in medicine. According to International Society of Hypertension, only in $60 \%$ of treated patients with $\mathrm{AH}$ have their blood pressure (BP) controlled [3]. The degree of target organs damage depends not only on the office BP level. It much more closely correlates with the mean night-time BP according to ambulatory BP monitoring (ABPM) data, as well as with the type of daily BP profile [4]. One of the methods for normalizing these indicators is chronotherapy, which in relation to $\mathrm{AH}$ is defined as taking at least one antihypertensive drug at bedtime. According to the results of some studies, in patients with hypertension, including those with concomitant pathologies such as diabetes mellitus, chronic kidney disease and obstructive sleep apnea, taking at least one antihypertensive drug at bedtime improves BP control, normalizes daily BP profile and reduces the risk of cardiovascular complications and mortality, compared with patients taking antihypertensive therapy once in the morning [5-7]. Increased blood pressure variability is currently considered as another risk factor for target organ damage and cardiovascular complications in patients with hypertension [8-10].

\section{Aim}

The aim of our study was to determine the various modes of antihypertensive therapy efficiency in terms of hypotensive medications dosing timing in the achievement of target BP levels and short-term BP variability according to the ABPM data in patients with $\mathrm{AH}$

\section{Materials and methods}

Patients with $\mathrm{AH}$ were examined on the basis of Kharkiv Outpatient Clinic No. 24. An inclusion criterion was previously diagnosed $\mathrm{AH}$ in patients older than 40 years.

103 patients between 41 and 78 years of age, median 61 , were enrolled. All the patients signed informed consent.
Exclusion criteria were hemodynamically significant valvular heart disease, cardiomyopathies of any origin, heart failure (HF) III-IV functional class (FC) by NYHA, any acute condition (infection, trauma, surgery) within the previous 3 months, chronic decompensated or acute illness, cancer, as well as any circumstances that could hinder the ambulatory blood pressure monitoring (ABPM) implementation.

The study involved 32 men $(31 \%)$ and 71 women (69\%). HF was diagnosed in the 77 cases (75\%): HF I FC was determined in 31 patients (30\%), II FC - 42 (41\%); coronary heart disease (CHD) - 81 cases $(79 \%)$ : stable angina (I-III FC) - 15 (15\%), postinfarction cardiosclerosis (PICS) - 5 (5\%), focal aterosclerotic cardiosclerosis (ACS) - $64(62 \%)$. Acute cerebrovascular events in anamnesis had $6(6 \%)$ patients.

The study participants were divided into 3 groups, depending on the mode of antihypertensive therapy: group 1 - patients who received antihypertensive drugs once daily, in the morning; group 2 - patients who received at least one antihypertensive drug at bedtime; group 3 - patients with low antihypertensive treatment compliance. Studied groups were comparable by sex and age.

All the patients were under standard antihypertensive therapy, in form of mono- or combined therapy, recommended by Ukrainian Association of Cardiologists 2016: angiotensin converting enzyme inhibitors - enalapril (5-20 mg/day), lisinopril (5-30 mg/day), perindopril (2-5 mg/day); angiotensin receptors blockers - valsartan (80-320 mg/day), losartan (50-100 mg/day); diuretics - hydrochlorothiazide $(6.25-25.00 \mathrm{mg} /$ day), indapamide (1.25-2.50 mg/day); calcium channels blockers - amlodipine (5-10 mg/day), lecarnidipine (10 $\mathrm{mg} /$ day); beta-blockers - bisoprolol (2.5-10.0 mg/day), nebivolol (2.5-7.5 mg/day).Combined therapy prevailed over monotherapy in all groups and amounted to $57 \%$ in group 1,70\% in group 2, $71 \%$ in group 3. Studied groups were comparable by a percentage of mono- and combined therapy.

All the patients underwent ABPM using the computer system "Cardiosens" (KhAl Medica, Ukraine) with an oscillometric method of BP measurement. The mean values of systolic BP (SBP) and diastolic BP (DBP) were estimated at different periods of monitoring. The periods of day and night
Ключевые слова: артериальная гипертензия, хронотерапия, вариабельность артериального Аавления, суточное мониторирование артериального Аавмения.

\section{Запорожский} медицинский журнал 2020. T. 22, № 3(120). C. $290-295$ 
Table 1. Levels of blood pressure, $\mathrm{M}, \mathrm{Me}$, [min-max] $(\mathrm{mmHg})$

\begin{tabular}{|c|c|c|c|c|}
\hline \multirow[t]{2}{*}{ Groups } & Group 1, n = 46 & Group 2, $n=43$ & Group 3, n= 14 & $\mathbf{P}$ \\
\hline & \multicolumn{4}{|l|}{ Office BP } \\
\hline SBP & & & & 0.564 \\
\hline M & 142 & 140 & 147 & \\
\hline $\mathrm{Me}$ & 140 & 140 & 148 & \\
\hline [min-max] & [105-220] & [110-185] & [125-180] & \\
\hline$D B P$ & & & & 0.053 \\
\hline M & 87 & 86 & 94 & \\
\hline $\mathrm{Me}$ & 83 & 90 & 98 & \\
\hline \multirow[t]{2}{*}[\operatorname{min}-\operatorname{max}]{} & {$[65-120]$} & [60-120] & [70-110] & \\
\hline & \multicolumn{3}{|l|}{ ABPM, 24-hours } & \\
\hline \multicolumn{4}{|l|}{$S B P$} & 0.10 \\
\hline M & 132 & 133 & 139 & \\
\hline $\mathrm{Me}$ & 129 & 129 & 140 & \\
\hline [min-max] & {$[101-190]$} & {$[104-163]$} & {$[125-155]$} & \\
\hline \multicolumn{4}{|l|}{$D B P$} & 0.02 \\
\hline M & 78 & 78 & 85 & \\
\hline $\mathrm{Me}$ & 77 & 78 & 86 & \\
\hline \multirow[t]{2}{*}[\operatorname{min}-\operatorname{max}]{} & {$[57-100]$} & {$[60-105]$} & {$[74-94]$} & \\
\hline & \multicolumn{3}{|l|}{ ABPM, awake BP } & \\
\hline \multicolumn{4}{|l|}{ SBP } & 0.09 \\
\hline M & 135 & 136 & 142 & \\
\hline $\mathrm{Me}$ & 132 & 132 & 142 & \\
\hline [min-max] & [104-193] & {$[107-166]$} & {$[130-155]$} & \\
\hline \multicolumn{4}{|l|}{$D B P$} & 0.03 \\
\hline M & 80 & 81 & 88 & \\
\hline $\mathrm{Me}$ & 80 & 82 & 89 & \\
\hline \multirow[t]{2}{*}[\operatorname{min}-\operatorname{max}]{} & {$[60-101]$} & {$[62-107]$} & [75-99] & \\
\hline & \multicolumn{3}{|c|}{ ABPM, nighttime $B P$} & \\
\hline \multicolumn{4}{|l|}{$S B P$} & 0.45 \\
\hline M & 122 & 123 & 128 & \\
\hline $\mathrm{Me}$ & 121 & 123 & 125 & \\
\hline [min-max] & [89-184] & [89-158] & {$[105-166]$} & \\
\hline \multicolumn{4}{|l|}{$D B P$} & 0.30 \\
\hline M & 69 & 69 & 73 & \\
\hline $\mathrm{Me}$ & 69 & 68 & 73 & \\
\hline \multirow[t]{2}{*}{ [min-max] } & {$[48-94]$} & [50-97] & [58-88] & \\
\hline & \multicolumn{3}{|l|}{ ABPM, morning BP } & \\
\hline$S B P$ & & & & 0.34 \\
\hline M & 133 & 135 & 138 & \\
\hline $\mathrm{Me}$ & 132 & 133 & 142 & \\
\hline$[\min -\max ]$ & {$[101-181]$} & {$[102-173]$} & {$[110-154]$} & \\
\hline$D B P$ & & & & 0.23 \\
\hline M & 80 & 82 & 86 & \\
\hline $\mathrm{Me}$ & 80 & 82 & 87 & \\
\hline [min-max] & [58-104] & [58-114] & [64-105] & \\
\hline
\end{tabular}

were determined by a patient's diary. The degree of sleeptime relative $\mathrm{BP}$ decline was calculated using the formula:

(100 × [mean awake BP - mean asleep BP] / mean awake $B P)$.

Depending on the value of this ratio, the following types of daily BP profile were defined:

"dipper" - physiological decrease in BP during the night - sleep-time relative BP decline more than $10 \%$;

"nondipper" - the lack of BP reduction at night, sleeptime relative $\mathrm{BP}$ decline $<10 \%$ [11].

The presence of night and morning hypertension, as well as SBP and DBP variability indices were estimated. BP variability was assessed using the following indices: VAR1 - the standard deviation from the mean
$B P$ value for a given time period; VAR2 - the root-meansquare value of the difference between consecutive BP measurements.

Data were expressed as percentages $(P)$, mean $(M)$, median (Me), minimum (min) and maximum (max). Analysis of the variables was carried out using Kruskal-Wallis ANOVA or $X^{2}$-test, as appropriate, with corrections for multiple comparisons. A two-sided $P$ value $<0.05$ was considered statistically significant.

\section{Results}

The office means of SBP in all 3 groups exceeded the recommended threshold [12]. Office DBP means in groups 1 and 2 corresponded to the category of high normal blood pressure, and in group 3 was higher than $90 \mathrm{mmHg}$. According to the ABPM data, the mean 24-h, daytime and nighttime SBP values in all studied groups exceeded the recommended target levels and only in the morning period - two hours after awakening - corresponded to the allowable values [13]. The mean DBP values in groups 1 and 2 did not exceed the normative values during all periods. In group 3 , the mean DBP value was higher than the recommended one during the entire monitoring period (Table 1).

Statistically significant differences were found for mean 24-h DBP values between groups 1 and 3,2 and $3(P=$ 0.02 ) and awake mean DBP values between groups 1 and $3(\mathrm{P}=0.03)$ (Table 1).

Table 2 presents the ratios of patients in the studied groups, depending on the grade of hypertension, established according to office BP measurements [12] and ABPM data [13] and the percentage of controlled, night and morning $\mathrm{AH}$.

Based on office BP measurements, the largest percentage was formed by patients with controlled $\mathrm{AH}$ in groups 1 and 2 , in group 3 - by patients of grade 2 and $3 \mathrm{AH}$. In groups 1 and 2, the proportions of patients with controlled hypertension were almost equal and three times higher than in group 3. According to the ABPM, in groups 1 and 3 , the largest percentage was formed by patients of 1 grade hypertension, in group 2 - with controlled hypertension. According to ABPM, patients with controlled hypertension were absent in group 3. In all the studied groups, patients with night and morning hypertension accounted for more than the half, with the highest rates in group 3. Statistically significant differences were found for controlled $\mathrm{AH}$, confirmed by ABPM method, between groups 1 and 3, 2 and $3(\mathrm{P}<0.05)$ (Table 2).

The means of sleep-time relative SBP decline in all groups corresponded to nondipper type and ranged from 9.1 to 9.9 , and the means of sleep-time relative DBP decline - to dipper type, ranged from 13.5 to 16.8 . Thus, dippers in all the groups constituted a smaller part than nondippers, with the smallest proportion in group 3. No statistically significant differences were found between the groups.

Table 3 presents the mean values of BP variability indices - VAR1 and VAR2. Statistically significant differences were found for VAR1 SBP ${ }_{\text {night }}$ between groups 1 and 3, 2 and 3 . The $p$ values are presented in the table.

In groups 1 and 2, patients with increased variability accounted for $54 \%$ and $53 \%$, respectively, in group $3-$ exactly half of all cases. 


\section{Discussion}

The highest values of SBP and DBP, both according to the office measurements and $A B P M$, during various monitoring periods, as expected, were observed in the group of patients with low compliance and in most cases exceeded the recommended target BP values. In group 3, the lowest percentage of controlled $\mathrm{AH}$ according office measurements was observed, and controlled AH was completely absent according to ABPM in this group. In general, there were no discrepancies between the values of BP obtained by different measurement methods.

It is noteworthy that the percentage of controlled and grade $3 \mathrm{AH}$ according to ABPM was lower in all the groups, compared with the proportion of the same category of patients according to the office BP measurement results. Regarding the grade $1 \mathrm{AH}$, the opposite situation was observed - according to the ABPM, there were more such patients than according to the office measurements. Additional analysis showed that according to the office measurements in $1 / 4$ of all patients, included in the study, the grade of $\mathrm{AH}$ was overestimated, and the same proportion of patients had an underestimated grade of $\mathrm{AH}$, when compared with the ABPM data.

Our data correspond to the results of other researchers. The estimates from current studies suggest that office BP measurements misdiagnose $\mathrm{AH}$, when the readings are sufficiently above the hypertension threshold of $140 / 90 \mathrm{~mm}$ $\mathrm{Hg}$ in a clinic but below outside the clinic. This phenomenon was described by Pickering and colleagues as white coat hypertension $(\mathrm{WCH})$, which is thought to occur because of the stress of the occasion [14]. Thus, Gorostidi et al. report that the prevalence of $\mathrm{WCH}$ ranged from $15.5-29.2 \%$ in untreated patients and the prevalence of false-resistant hypertension due to the white-coat effect ranged from $24.2 \%$ in treated males to $37.5 \%$ in hypertensives resistant to three or more drugs [15].

The other less commonly than WCH recognized phenomenon is masked hypertension $(\mathrm{MH})$, where the patient's office BP levels are below the hypertension threshold of $140 / 90 \mathrm{~mm} \mathrm{Hg}$ but are above outside the clinic [16]. Banegas and colleagues report $\mathrm{MH}$ prevalence of $30 \%$ among treated hypertensive patients [17].

Thus, taken together, misdiagnosis of $\mathrm{AH}$ grade can occur in $20 \%$ to $30 \%$ of patients if classified with office BP measurements, which corresponds to our data.

All this confirms the need for widespread use of ABPM in clinical practice for the management of $\mathrm{AH}$ patients, since the percentage of patients with over - or undervalued degree of $\mathrm{AH}$ is quite large.

Despite the growing evidence that the evening taking of antihypertensive drugs helps to normalize the daily BP profile $[18,19]$, our study did not confirm this hypothesis.

In our study, nondippers prevailed in all the groups, regardless of the time of antihypertensive drugs intake. Although among patients, who received treatment regularly, this percentage was slightly lower than in patients with low compliance.

$\mathrm{BP}$ is a dynamic index; its fluctuations are a physiological phenomenon determined by the influence of different external and internal factors. Nowadays there is an increasing number of clinical and observational studies data indicating that increased BP variability increases the risk of cardiovascular complications and death, regardless
Table 2. Grade of arterial hypertension, controlled, night and morning arterial hypertension, \%

\begin{tabular}{|c|c|c|c|}
\hline & group $1, n=46$ & group $2, n=43$ & group $3, n=14$ \\
\hline & \multicolumn{3}{|c|}{ Office BP measurements } \\
\hline AH grade 1 & 24 & 28 & 36 \\
\hline AH grade 2 & 22 & 19 & 36 \\
\hline AH grade 3 & 13 & 12 & 14 \\
\hline \multirow[t]{2}{*}{ Controlled AH } & 41 & 42 & 14 \\
\hline & \multicolumn{3}{|l|}{ ABPM } \\
\hline AH grade 1 & 48 & 33 & 64 \\
\hline AH grade 2 & 11 & 30 & 29 \\
\hline AH grade 3 & 4 & 2 & 7 \\
\hline Controlled $\mathrm{AH}^{*}$ & 37 & 35 & 0 \\
\hline Night AH & 57 & 56 & 79 \\
\hline Morning AH & 52 & 56 & 64 \\
\hline
\end{tabular}

*: $\mathrm{P}<0.05$ between groups 1 and 3,2 and 3 .

Table 3. Blood pressure variability according to ambulatory blood pressure monitoring, $\mathrm{M}, \mathrm{Me}$, [min-max] $(\mathrm{mmHg})$

\begin{tabular}{|c|c|c|c|c|}
\hline Group & group $1, n=46$ & group $2, n=43$ & group $3, n=14$ & $P$ \\
\hline \multicolumn{5}{|l|}{ VAR 1 Day } \\
\hline SBP & & & & 0.79 \\
\hline$M$ & 14 & 14 & 15 & \\
\hline $\mathrm{Me}$ & 14 & 14 & 15 & \\
\hline [min-max] & {$[6-25]$} & [9-22] & [11-18] & \\
\hline DBP & & & & 0.93 \\
\hline M & 11 & 11 & 11 & \\
\hline $\mathrm{Me}$ & 11 & 10 & 11 & \\
\hline [min-max] & [4-19] & {$[6-24]$} & {$[7-16]$} & \\
\hline \multicolumn{5}{|l|}{ VAR 1 Night } \\
\hline SBP & & & & 0.01 \\
\hline$M$ & 13 & 13 & 10 & \\
\hline $\mathrm{Me}$ & 12 & 13 & 9 & \\
\hline [min-max] & [6-23] & [5-19] & {$[5-16]$} & \\
\hline DBP & & & & 0.10 \\
\hline M & 10 & 10 & 8 & \\
\hline $\mathrm{Me}$ & 9 & 10 & 8 & \\
\hline [min-max] & [5-20] & [4-17] & [6-12] & \\
\hline \multicolumn{5}{|l|}{ VAR 2 Day } \\
\hline SBP & & & & 0.60 \\
\hline M & 15 & 16 & 16 & \\
\hline $\mathrm{Me}$ & 15 & 16 & 16 & \\
\hline [min-max] & [7-27] & [10-26] & [13-22] & \\
\hline DBP & & & & 0.90 \\
\hline$M$ & 12 & 13 & 12 & \\
\hline $\mathrm{Me}$ & 11 & 12 & 12 & \\
\hline [min-max] & [5-22] & [7-35] & [8-20] & \\
\hline \multicolumn{5}{|l|}{ VAR 2 Night } \\
\hline SBP & & & & 0.27 \\
\hline$M$ & 16 & 16 & 14 & \\
\hline $\mathrm{Me}$ & 14 & 16 & 13 & \\
\hline [min-max] & [6-29] & [8-26] & [9-20] & \\
\hline DBP & & & & 0.67 \\
\hline $\mathrm{M}$ & eleven & 12 & eleven & \\
\hline $\mathrm{Me}$ & eleven & eleven & eleven & \\
\hline [min-max] & [5-18] & [7-25] & {$[6-14]$} & \\
\hline
\end{tabular}

of BP level [20]. Gosmanova [21] and Mehlum [22] with their colleagues showed that in patients with and without $\mathrm{AH}$, higher BP variability was associated with increased risks of all-cause mortality, ischemic heart disease, stroke, and end-stage renal disease. Stevens at al. presented 
the meta-analysis where the short-term BP variability was associated with cardiovascular and mortality outcomes [23]. Increased BP variability can also indicate the lack of antihypertensive therapy benefit, and therefore the optimization of antihypertensive treatment from the standpoint of pronounced BP fluctuations correction is seems to be important. The results of our study showed that the mode of antihypertensive therapy does not affect the short-term variability of $\mathrm{BP}$. The mean values of the variability indices were equal or slightly differed between the groups, and the differences revealed were statistically significant only when comparing the group of low compliance with the groups using antihypertensive drugs regularly. There were no significant differences between any of the studied parameters between the groups with the morning and evening dosing of antihypertensive drugs.

\section{Conclusions}

1. Regular intake of antihypertensive drugs helps to reduce the level of blood pressure and normalize its variability, regardless of the time of taking the drugs.

2. In clinical practice, the most informative method for assessing the effectiveness of blood pressure control is the ABPM in the management of patients with hypertension.

3. The results obtained necessitate the widespread introduction into clinical practice ABPM in order to avoid under- and overdiagnosis of $\mathrm{AH}$.

4. According to our data, the treatment mode does not significantly affect the short-term variability of blood pressure, determined by the standard deviation from the mean $\mathrm{BP}$ and the root-mean-square value of the difference between consecutive BP measurements for a given time period.

Prospects for further research. It seems perspective to evaluate the effect of various treatment modes on shortterm variability of BP using other variability indices that are less susceptible to external factors.

\section{Funding}

The study was conducted in the framework of the research work of V. N. Karazin Kharkiv National University "Pharmacological and interventional approaches to the treatment of patients with heart rhythm disorders and arterial hypertension", state registration number 0116 U000973.

Conflicts of interest: authors have no conflict of interest to declare. Конфмікт інтересів: віАсутній.

Надійшка Ао реАакції / Received: 29.05.2019

Після Аоопрацювання / Revised: 30.10.2019

Прийнято Ао Аруку / Accepted: 01.11.2019

Information about authors:

Kanishcheva O. V., MD, Assistant of the Internal Medicine Department, V. N. Karazin Kharkiv National University, Ukraine. ORCID ID: 0000-0002-2955-5478

Shop I. V., MD, PhD, Associate Professor of the Internal Medicine Department, V. N. Karazin Kharkiv National University, Ukraine. ORCID ID: 0000-0002-2027-3335

Tykhonova T. M., MD, PhD, DSc, Senior Researcher, Head of the Internal Medicine Department, V. N. Karazin Kharkiv National University, Ukraine.
Imanova N. I., MD, PhD, Associate Professor of the Therapy Department, Kharkiv Medical Academy of Postgraduate Education, Ukraine.

ORCID ID: 0000-0002-3092-4138

Pochynska M. V., MD, Assistant of the Internal Medicine Department, V. N. Karazin Kharkiv National University, Ukraine. ORCID ID: 0000-0001-6332-9266

\section{Відомості про авторів:}

Каніщева О. В., асистент каф. внутрішньої медицини, Харківський національний університет імені В. Н. Каразіна, україна.

Шоп І. В., канА. меА. наук, Аоцент каф. внутрішньої меАицини, Харківський національний університет імені В. Н. Каразіна, україна.

Тихонова Т.М., А-р меА. наук, старший науковий співробітник, зав. каф. внутрішньої медицини, Харківський національний університет імені В. Н. Каразіна, Україна.

Іманова Н. І., канА. меА. наук, Аоцент каф. терапії, Харківська медична академія післядипломної освіти, Україна.

Починська М. В., асистент каф. внутрішньої медицини, Харківський національний університет імені В. Н. Каразіна, Україна.

\section{Сведения об авторах}

Канищева Е. В., ассистент каф. внутренней медицины, Харьковский национальный университет имени В. Н. Каразина, Украина.

Шоп И. В., канА. меА. наук, Аоцент каф. внутренней медицины, Харьковский национальный университет имени В. Н. Каразина, Украина.

Тихонова Т.М., А-р меА. наук, старший научный сотрудник, зав. каф. внутренней медицины, Харьковский национальный университет имени В. Н. Каразина, Украина.

Иманова Н. И., канд. меА. наук, доцент каф. терапии, Харьковская медицинская академия последипломного образования, Украина.

Починская М. В., ассистент каф. внутренней медицины, Харьковский национамьный университет имени В. Н. Каразина, Украина.

\section{References}

[1] Ettehad, D., Emdin, C. A., Kiran, A., Anderson, S. G., Callender, T. Emberson, J., Chalmers, J., Rodgers, A., \& Rahimi, K. (2016). Blood pressure lowering for prevention of cardiovascular disease and death: a systematic review and meta-analysis. The Lancet, 387(10022), 957967. https://doi.org/10.1016/s0140-6736(15)01225-8

[2] Stanaway, J. D., Afshin, A., Gakidou, E., Lim, S. S., Abate, D., Abate, K. H., Abbafati, C., Abbasi, N., Abbastabar, H., Abd-Allah, F. Abdela, J., Abdelalim, A., Abdollahpour, I., Abdulkader, R. S., Abebe, M., Abebe, Z., Abera, S. F., Abil, O. Z., Abraha, H. N., ... Murray, C. J. L. (2018). Global, regional, and national comparative risk assessment of 84 behavioural, environmental and occupational, and metabolic risks or clusters of risks for 195 countries and territories, 1990-2017: a systematic analysis for the Global Burden of Disease Study 2017 The Lancet, 392(10159), 1923-1994. https://doi.org/10.1016/s01406736(18)32225-6

[3] Beaney, T., Burrell, L. M., Castillo, R. R., Charchar, F. J., Cro, S., Damasceno, A., Kruger, R., Nilsson, P. M., Prabhakaran, D., Ramirez, A. J., Schlaich, M. P., Schutte, A. E., Tomaszewski, M., Touyz, R., Wang, J. -G., Weber, M. A., Poulter, N. R., Burazeri, G., Qirjako, G., ... Xia, X. (2019). May Measurement Month 2018: a pragmatic global screening campaign to raise awareness of blood pressure by the International Society of Hypertension. European Heart Journal, 40(25), 2006-2017. https://doi.org/10.1093/eurhearti/ehz300

[4] Niiranen, T. J., Mäki, J., Puukka, P., Karanko, H., \& Jula, A. M. (2014) Office, Home, and Ambulatory Blood Pressures as Predictors of Cardiovascular Risk. Hypertension, 64(2), 281-286. https://doi.org/10.1161/ hypertensionaha. 114.03292

[5] American Diabetes Association (2018) 9 . Cardiovascular Disease and Risk Management:Standards of Medical Care in Diabetes - 2018. Diabetes Care, 41(Suppl. 1), S86-S104. https://doi.org/10.2337/dc18-s009

[6] Hermida, R. C., Ayala, D. E.,Fernández, J. R., Mojón, A., \& Smolensky, M. H. (2018). Hypertension: New perspective on its definition and clinical management by bedtime therapy substantially reduces cardiovascular disease risk. European Journal of Clinical Investigation, 48(5), Article e12909. https://doi.org/10.1111/eci.12909 
[7] Bowles, N. P., Thosar, S. S., Herzig, M. X., \& Shea, S. A. (2018). Chronotherapy for Hypertension. Current Hypertension Reports, 20(11). https://doi.org/10.1007/s11906-018-0897-4

[8] Zawadzki, M. J., Small, A. K., \& Gerin, W. (2017). Ambulatory blood pressure variability. Blood Pressure Monitoring, 22(2), 53-58. https:// doi.org/10.1097/mbp.00000000000000230

[9] Weber, M. A. (2017). Blood pressure variability and cardiovascular prognosis: implications for clinical practice. European Heart Journal, 38(37), 2823-2826. https://doi.org/10.1093/eurhearti/ehx322

[10] Chowdhury, E. K., Wing, L. M. H., Jennings, G. L. R., Beilin, L. J., \& Reid, C. M. (2018). Visit-to-visit (long-term) and ambulatory (short-term) blood pressure variability to predict mortality in an elderly hypertensive population. Journal of Hypertension, 36(5), 1059-1067. https://doi. org/10.1097/hih. 0000000000001652

[11] Hermida, R. C., Smolensky, M. H., Ayala, D. E., Portaluppi, F., Crespo, J. J., Fabbian, F., Haus, E., Manfredini, R., Mojón, A., Moyá, A., Piñeiro, L., Ríos, M. T., Otero, A., Balan, H., \& Fernández, J. R. (2013). 2013 Ambulatory Blood Pressure Monitoring Recommendations for the Diagnosis of Adult Hypertension, Assessment of Cardiovascular and other Hypertension-associated Risk, and Attainment of Therapeutic Goals. Chronobiology International, 30(3), 355-410. https://doi.org/10. 3109/07420528.2013.750490

[12] Williams, B., Mancia, G., Spiering, W., Agabiti Rosei, E., Azizi, M., Burnier, M., Clement, D. L., Coca, A., de Simone, G., Dominiczak, A., Kahan, T., Mahfoud, F., Redon, J., Ruilope, L., Zanchetti, A., Kerins, M., Kjeldsen, S. E., Kreutz, R., Laurent, S., ... Brady, A. (2018). 2018 ESC/ESH Guidelines for the management of arterial hypertension. European Heart Journal, 39(33), 3021-3104. https://doi.org/10.1093/ eurheartj/ehy339

[13] Head, G. A. (2014). Ambulatory Blood Pressure Monitoring Is Ready to Replace Clinic Blood Pressure in the Diagnosis of Hypertension. Hypertension, 64(6), 1175-1181. https://doi.org/10.1161/hypertensionaha.114.03882

[14] Pickering, T. G., Gerin, W., \& Schwartz, A. R. (2002). What is the whitecoat effect and how should it be measured? Blood Pressure Monitoring, 7(6), 293-300. https://doi.org/10.1097/00126097-200212000-00001

[15] Gorostidi, M., Vinyoles, E., Banegas, J. R., \& de la Sierra, A. (2014). Prevalence of white-coat and masked hypertension in national and international registries. Hypertension Research, 38(1), 1-7. https://doi. org/10.1038/hr.2014.149

[16] Pickering, T. G., Eguchi, K., \& Kario, K. (2007). Masked Hypertension: A Review. Hypertension Research, 30(6), 479-488. https://doi. org/10.1291/hypres.30.479

[17] Banegas, J. R., Ruilope, L. M., de la Sierra, A., de la Cruz, J. J., Gorostidi, M., Segura, J., Martell, N., Garcia-Puig, J., Deanfield, J., \& Williams, B. (2014). High prevalence of masked uncontrolled hypertension in people with treated hypertension. European Heart Journal, 35(46), 3304-3312. https://doi.org/10.1093/eurheartj/ehu016

[18] Sun, Y., Yu, X., Liu, J., Zhou, N., Chen, L., Zhao, Y., Li, X., Wang, J., \& Cui, L. (2016). Effect of bedtime administration of blood-pressure lowering agents on ambulatory blood pressure monitoring results: A meta-analysis. Cardiology Journal, 23(4), 473-481. https://doi. org/10.5603/ci.a2016.0027

[19] Carter, B. L., Chrischilles, E. A., Rosenthal, G., Gryzlak, B. M., Eisenstein, E. L., \& Vander Weg, M. W. (2013). Efficacy and Safety of Nighttime Dosing of Antihypertensives: Review of the Literature and Design of a Pragmatic Clinical Trial. The Journal of Clinical Hypertension, 16(2), 115-121. https://doi.org/10.1111/jch.12238

[20] Vishram, J. K. K., Dahlöf, B., Devereux, R. B., Ibsen, H., Kjeldsen, S. E. Lindholm, L. H., Mancia, G., Okin, P. M., Rothwell, P. M., Wachtell, K., \& Olsen, M. H. (2015). Blood pressure variability predicts cardiovascular events independently of traditional cardiovascular risk factors and target organ damage. Journal of Hypertension, 33(12), 2422-2430. https:// doi.org/10.1097/hih.0000000000000739

[21] Gosmanova, E. O., Mikkelsen, M. K., Molnar, M. Z., Lu, J. L., Yessayan, L. T., Kalantar-Zadeh, K., \& Kovesdy, C. P. (2016). Association of Systolic Blood Pressure Variability With Mortality, Coronary Heart Disease, Stroke, and Renal Disease. Journal of the American College of Cardiology, 68(13), 1375-1386. https://doi.org/10.1016/j. jacc.2016.06.054

[22] Mehlum, M. H., Liestøl, K., Kjeldsen, S. E., Julius, S., Hua, T. A., Rothwell, P. M., Mancia, G., Parati, G., Weber, M. A., \& Berge, E. (2018). Blood pressure variability and risk of cardiovascular events and death in patients with hypertension and different baseline risks. European Heart Journal, 39(24), 2243-2251. https://doi.org/10.1093/eurhearti/ehx760

[23] Stevens, S. L., Wood, S., Koshiaris, C., Law, K., Glasziou, P., Stevens, R. J., \& McManus, R. J. (2016). Blood pressure variability and cardiovascular disease: systematic review and meta-analysis. British Medical Journal, 354, Article i4098. https://doi.org/10.1136/bmj.i4098 